\title{
Iron catalyzed highly enantioselective epoxidation of cyclic aliphatic enones with aqueous $\mathrm{H} 2 \mathrm{O} 2$
}

Olaf Cussó, Marco Cianfanelli, Xavi Ribas, Robertus J.M. Klein Gebbink, and Miquel Costas J. Am. Chem. Soc., Just Accepted Manuscript • DOI: 10.1021/jacs.5b12681 • Publication Date (Web): 22 Jan 2016 Downloaded from http://pubs.acs.org on February 10, 2016

\section{Just Accepted}

"Just Accepted" manuscripts have been peer-reviewed and accepted for publication. They are posted online prior to technical editing, formatting for publication and author proofing. The American Chemical Society provides "Just Accepted" as a free service to the research community to expedite the dissemination of scientific material as soon as possible after acceptance. "Just Accepted" manuscripts appear in full in PDF format accompanied by an HTML abstract. "Just Accepted" manuscripts have been fully peer reviewed, but should not be considered the official version of record. They are accessible to all readers and citable by the Digital Object Identifier (DOI囚). "Just Accepted" is an optional service offered to authors. Therefore, the "Just Accepted" Web site may not include all articles that will be published in the journal. After a manuscript is technically edited and formatted, it will be removed from the "Just Accepted" Web site and published as an ASAP article. Note that technical editing may introduce minor changes to the manuscript text and/or graphics which could affect content, and all legal disclaimers and ethical guidelines that apply to the journal pertain. ACS cannot be held responsible for errors or consequences arising from the use of information contained in these "Just Accepted" manuscripts. 
Introduction. Asymmetric epoxidation is a valuable reaction because chiral epoxides are versatile building blocks in synthetic organic chemistry. ${ }^{1-4}$ Catalytic epoxidation methodologies based on iron complexes and peroxides (especially $\mathrm{H}_{2} \mathrm{O}_{2}$ ), which can be considered as biologically inspired, are interesting because of the availability and low environmental impact of these reagents. ${ }^{5-15,16}$ Despite appealing, the approach is challenging because it requires the design of iron coordination complexes that can activate the $\mathrm{O}-\mathrm{O}$ bond of peroxides to create selective metal based oxidants, and avoid the often facile production of hydroxyl radicals via the Fenton reaction. $^{10,11,17,18}$ Recent reports have disclosed successful examples where asymmetric epoxidation is accomplished, in some cases producing high levels of stereoselectivity (Figure 1). ${ }^{19-27}$ Highly enantioselective epoxidation of difficult substrates such as $\beta, \beta$-disubstituted aromatic enones and $\alpha$-alkyl styrenes, not accessible by other methods, have also been described. ${ }^{23,24}$ However, a major limitation still resides at the fact that iron catalyzed asymmetric epoxidations have been limited in scope to olefins conjugated to aromatic rings, ${ }^{19-}$ $22,23,24-35$ and remains to be accomplished for aliphatic substrates. Particularly interesting are cyclic aliphatic enones. Cyclic $\alpha$-epoxide enones are structures found in a number of natural products, ${ }^{36}$ and are also valuable synthons that can be further elaborated into precious building blocks for organic synthesis. ${ }^{37}$ However, their asymmetric epoxidation is notoriously difficult. Modest to good enantioselectivities have been obtained with chiral hydroperoxides, ${ }^{38,39}$ poly(aminoacids) catalysts, ${ }^{40}$ ammonium salt catalysts, ${ }^{41-43}$ and metal based catalysts ${ }^{21,22,44,45}$, but excellent enantioselectivities have only been described by List and co-workers using cinchona alkaloid derived organocatalysts and hydrogen peroxide as oxidant. The main drawbacks of this system are the requirement of relatively high catalyst loadings (up to $10 \%$ ) and long reaction times (from 24 to $168 \mathrm{~h}$ ). In addition, $\alpha$ and $\alpha$ substituted enones are not valid substrates for the system. Highly enantioselective epoxidations that could improve these aspects will be a competitive alternative. In this regard, an iron catalyzed $\mathrm{H}_{2} \mathrm{O}_{2}$-activation methodology was envisioned as a potential option because they commonly entail powerful, fast reacting oxidants. ${ }^{12}$ On the other hand, the high reactivity of this kind of systems can be rapidly recognized as a challenging aspect for elaborating them into highly enantioselective catalysts.

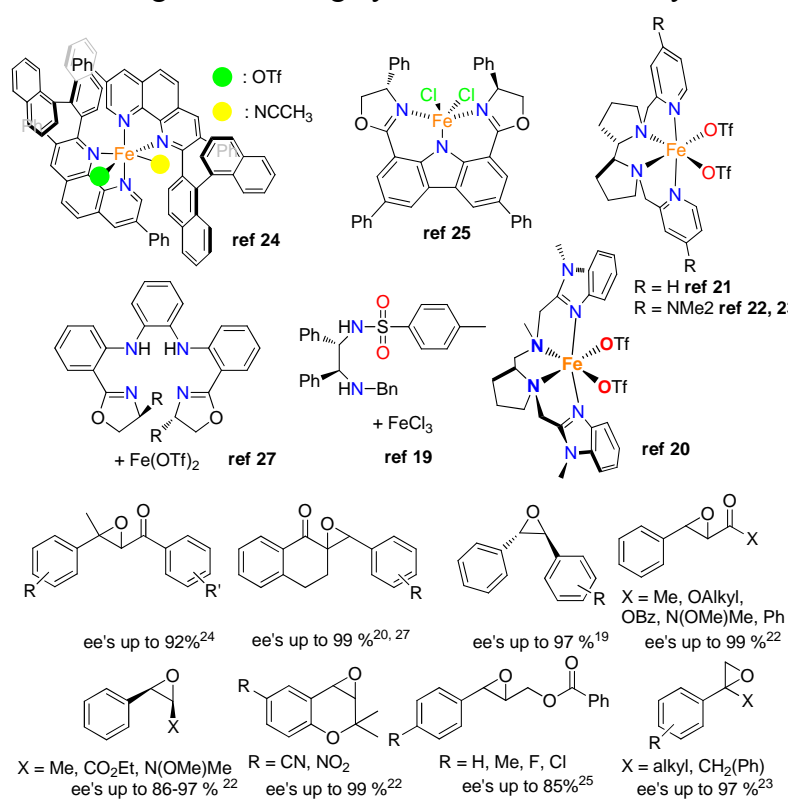

Figure 1. Representative examples of iron catalysts for asymmetric epoxidations, and current substrate scope.

Herein we face some of these challenges by describing the first example of an iron catalyst that epoxidizes cyclic aliphatic enones in high yields and with good to excellent stereoselectivities, employing $\mathrm{H}_{2} \mathrm{O}_{2}$ as oxidant. The optimum catalyst is $\mathrm{C}_{1}$-symmetric and contains a tetradentate ligand built in a 
modular manner by combining a bulky picoline, a benzylimidazole ring, and a chiral bipyrrolidine (catalyst 7, Figure 2). Reactions are fast (30 min) and require relatively low catalysts loadings (1-3 mol\%). Finally, it is shown that the current system operates via generation of an electrophilic oxidant, therefore differing mechanistically from asymmetric epoxidation methods described so far for this class of substrates, which operate via a Weitz-Scheffer ${ }^{46-51}$ mechanism where nucleophilic oxidants account for the epoxidation reaction. We show that this element represents a valuable tool for performing site selective epoxidation of enones containing two alkene sites, with orthogonal selectivity with regard to Weitz-Scheffer epoxidation agents.

Results and discussion.

Catalyst screening. Our initial screening entailed epoxidation of cyclohexenone S1, employing different iron catalysts (details on the preparation, and characterization of the ligands and the complexes are collected in the supporting information) with tetradentate N-based ligands ( $1 \mathrm{~mol} \%)$, hydrogen peroxide as oxidant (2.3 equiv.) and ethylhexanoic acid (2-eha, 1.4 equiv.) as additive necessary for helping in the controlled activation of the $\mathrm{H}_{2} \mathrm{O}_{2}$ (Table 1). ${ }^{21,22}$ Reactions were performed at $-30^{\circ} \mathrm{C}$ by adding $\mathrm{H}_{2} \mathrm{O}_{2}$ (during $30 \mathrm{~min}$ ) via syringe pump to an acetonitrile solution of the substrate, the catalysts and 2-eha under air. Following $\mathrm{H}_{2} \mathrm{O}_{2}$ addition, reactions were analyzed by gas chromatography to determine conversion, epoxide yield, and stereoselectivity. Results are collected in Table 1.

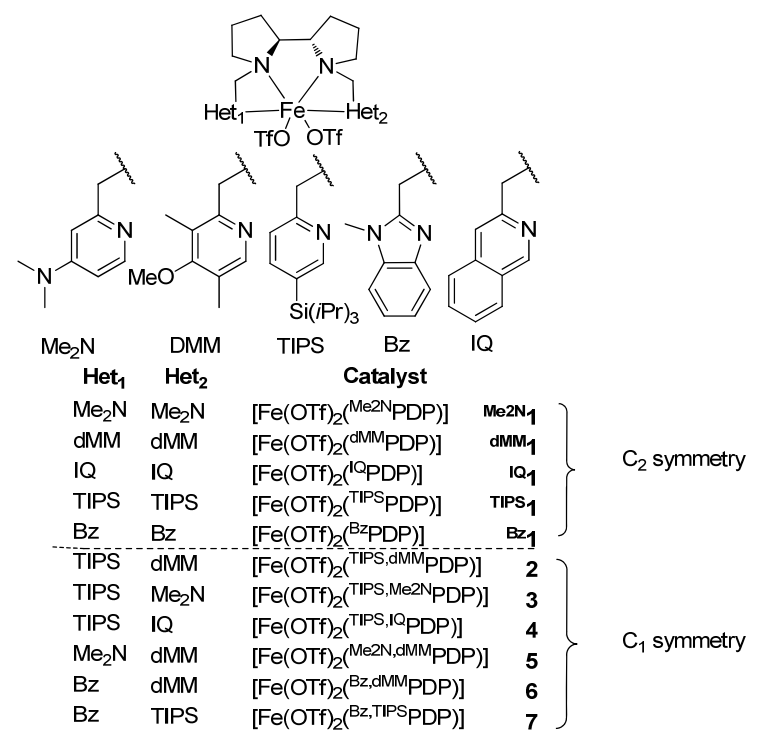

Figure 2. Schematic diagram of different catalysts employed.

Iron catalysts employed in the initial screening entailed $\mathrm{C}_{2}$ - symmetric complexes containing tetradentate ligands based on a bis-pyrrolidine and two-heterocyclic amine

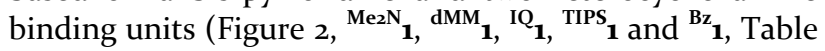
1 , entries 1-5). The heterocycles included electron-rich pyridines (entries $1-2, M_{1} \mathbf{N}_{1}$ and ${ }^{\mathbf{d M M}_{1}}$ ), bulky pyridines (entry 4, ${ }^{\text {TIPS }} \mathbf{1}$ ), isoquinoline (entry $3,{ }_{1}$ ) and also Nmethyl-benzylimidazole (entry $\left.5,{ }^{\mathrm{Bz}} \mathbf{1}\right)$. We were quite pleased to observe that the complexes provided good to excellent ee's (from 72 to $88 \%$ ee) in the epoxidation of

the model substrate. However, the best stereoselection, delivered by the benzymidazole based catalyst ${ }^{\mathbf{B z}} \mathbf{1}$, was accompanied by poor product yield ( $88 \%$ ee, $5 \%$ epoxide yield, entry 5 ). Systems based on two pyridine rings (entries 1-4), provide smaller stereoselectivities (72-84\% ee) but good product yields (71-94\%). $\mathrm{C}_{1}$-symmetric complexes (2-7) with distinct heterocyclic arms were subsequently considered (entries 6-12). Most interestingly, catalysts that combine a methyl-imidazole ring and either an e-rich pyridine (6, entry 10$)$, or a bulky pyridine (7, entries 11-12) provided the corresponding epoxide with excellent enantioselectivities (88-90 ee). In the case of 7, the epoxide was obtained in a modest $55 \%$ yield that could be subsequently optimized to a good yield (86\%) while retaining the high level of enantioselectivity by employing $3 \mathrm{~mol} \%$ catalyst. Replacement of 2-eha by other carboxylic ac$\operatorname{ids}^{22,23}$ did not produce an improvement in the stereoselectivity of the reaction.

Characterization of the catalyst. Structural characterization of 7 in the solid state was accomplished by single crystal X-ray diffraction analysis (Figure 3, and SI for crystallographic details). The structure corresponds to an octahedrally coordinated iron center, adopting a cis- $\alpha$ topological geometry, with the two heterocycles trans to each other and the two labile triflate anions cis to each other. The binding $\mathrm{O}$ atoms of the triflate ligands and the iron center define a plane roughly perpendicular to an hypothetical $\mathrm{N}_{\text {py }}-\mathrm{N}_{\text {BzIm }}$ axis. Fe-N and Fe-O distances are 2.1-2.2 $\AA$, indicative of a high spin center. ${ }^{1} \mathrm{H}-\mathrm{NMR}$ analyses in $\mathrm{CD}_{3} \mathrm{CN}$ indicate that the high spin state is retained in solution, being the number of signals consistent with its $\mathrm{C}_{1}$ symmetry (see $\mathrm{SI}$ ).

Table 1. Screening of the iron complexes in the asymmetric epoxidation reaction of 2-cyclohexenone

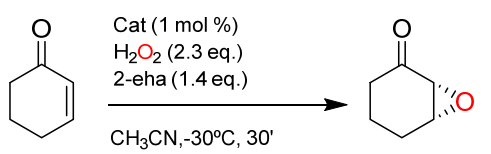

\begin{tabular}{|c|c|c|c|}
\hline Entry & Catalyst & Conv(yield) $\%^{\mathrm{a}}$ & $(\mathrm{ee}) \%$ \\
\hline 1 & ${ }^{\text {Me2N }} 1$ & $85(73)$ & 75 \\
\hline 2 & $\mathrm{dmM}_{1}$ & $100(94)$ & 84 \\
\hline 3 & ${ }^{\mathrm{IO}} 1$ & $98(81)$ & 72 \\
\hline 4 & ${ }^{\mathrm{TIPS}_{1}} 1$ & $87(71)$ & 81 \\
\hline 5 & ${ }^{{ }^{\mathrm{B}} \mathbf{1}} \mathbf{1}$ & $26(5)$ & 88 \\
\hline 6 & 2 & $100(87)$ & 85 \\
\hline 7 & 3 & $90(72)$ & 74 \\
\hline 8 & 4 & $100(70)$ & 75 \\
\hline 9 & 5 & $99(80)$ & 77 \\
\hline 10 & 6 & $73(60)$ & 88 \\
\hline
\end{tabular}




$\begin{array}{llll}11 & 7 & 67(55) & 90 \\ { }^{\mathrm{b}} 12 & 7 & 100(86) & 90\end{array}$

Unless stated, reaction conditions are $\left(S, S^{\prime}\right)$-catalyst ( $\left.1 \mathrm{~mol} \%\right)$, $\mathrm{H}_{2} \mathrm{O}_{2}$ (2.3 equiv) and 2-eha (1.4 equiv.) in $\mathrm{CH}_{3} \mathrm{CN}$ at $-30^{\circ} \mathrm{C}$ during $30 \mathrm{~min}$. ${ }^{\mathrm{a}}$ Epoxide yields and substrate conversion determined by GC. Ee's determined by GC with a chiral stationary phase. The absolute configuration $(2 R, 3 R)$ of the epoxide was determined from its optical rotation, and by comparison from the literature. ${ }^{21 \mathrm{~b}}$ $3 \mathrm{~mol} \%$ of catalyst.

Figure 3. ORTEP diagram of the single crystal X-ray determined structure of $\left(S, S^{\prime}\right)-7$ is shown. Triflate groups were omitted for clarity, except for the oxygen atoms directly bound to the iron center.
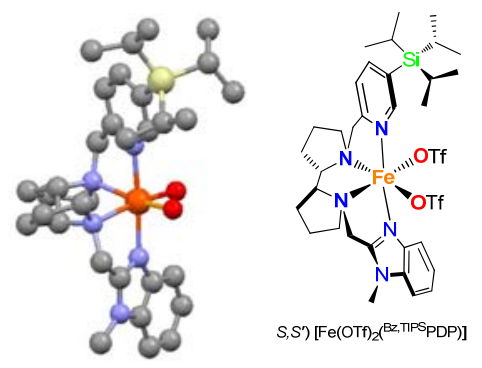

Substrate scope. The substrate scope in the asymmetric epoxidation of a series of cyclic aliphatic enones (Table 2) catalyzed by 7 was determined using the optimized conditions. In first place, it was observed that epoxidation of 2cyclopentenone, a substrate that is recognized as particularly challenging, ${ }^{36}$ proceeds with excellent yield and enantioselectivity (Table 2, entry 1), but an slight erosion of stereoselectivity was observed when the enone ring was enlarged up to 7 and 8 member rings $(84 \%$ and $81 \%$ ee, respectively, entries 3 and 4$)$. Substitutions in the two sides of the cyclic enone produced different effects in the level of enantioselectivity of the reactions. In general, substitutions at the olefinic side $(\alpha$ and $\beta$ ) decrease ee's, while substitutions at the opposite side $(\alpha$ ' and $\beta^{\prime}$ ) lead to important improvement. For example, alkyl substitution at the $\alpha$ position of 5 and 6 -member ring enones caused a significant decrease in ee's (62-65\% ee, entries 5-6), that could be partially rescued by employing 2 as catalyst (for S5 75\% yield and $76 \%$ ee, and for S6 $81 \%$ yield and 75\% ee). Also, for tert-butyl group in $\alpha$ position the reaction didn't take place (entry 7, S7).Although the current ee values leave room for improvement, it should be stated that the current catalysts constitute the first ones that provide good enantioselectivities for these substrates. $\beta$-alkylated cyclic enones gave also slightly lower enantioselectivities in comparison with the parent cyclic unsubstituted enones (see entries 8-13); isopropyl and ethyl $\beta$-substitution in 2-cyclohexenone provided the more modest ee's (66 and $70 \%$ ee, entries 13 and 10, respectively) while $\beta$-alkyl substituted 2-cyclohexenones with methyl, propyl and butyl chains are epoxidized with high enantioselection (entries 9, 11 and 12,80-84\% ee). Most interestingly, the introduction of a gem-dimethyl group at positions $\alpha^{\prime}, \beta$, or $\gamma$ results in a very substantial improvement of the enantioselectivities. Particularly outstanding enantioselectivities were obtained for substrates with gem-dimethyl substitution in position $\alpha^{\prime}$ (entries $15-18,90-95 \%$ ee). This is a particularly relevant result since there is no alternative method for the asymmetric epoxidation of this type of substrates. Substitution at position $\beta$ ' also provided high enantiomeric excesses (between 85 and $91 \%$ ee, entries 14, 19-22). Of notice, natural product isophorone (entry 19) was epoxidized in $71 \%$ isolated yield and $89 \%$ ee. Substitution at position $\gamma$ also enhanced enantioselectivity ( $92 \%$ ee, entry 23$)$, although in this case the epoxide was obtained in a modest $35 \%$ isolated yield. The relatively modest yields of epoxides bearing bulky and rigid substituents in close proximity to the olefinic site (entries 12 and 22) suggest that steric hindrance may be limiting these reactions.

Table 2. Substrate scope of aliphatic cyclic enones in asymmetric epoxidation reaction with 7 as catalyst

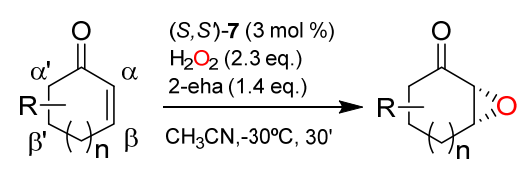

Entry

Substrate

Isol. yield (\%)

(ee) $\%$<smiles>O=C1C=CCC1</smiles><smiles>O=C1C=CCCC1</smiles><smiles>O=C1C=C[C+]([AsH3])CC1</smiles><smiles>O=C1C=CCCCC1</smiles><smiles>CC1=CCCC1=O</smiles><smiles>CC1=CCCCC1=O</smiles><smiles>CC(C)(C)C1=CCCCC1=O</smiles><smiles>O=C1C=C([AsH2])CC1</smiles><smiles>O=C1C=C([AsH2])CCC1</smiles> 
(S10)<smiles>O=C1C=C(CC[AsH2])CCC1</smiles><smiles>O=C1C=C([151I][Ba])CCC1</smiles><smiles>CC(C)C1CCCC(=O)C1</smiles><smiles>CC1(C)CC=CC(=O)C1</smiles><smiles>CC1(C)CCC=CC1=O</smiles><smiles>CC1(C)CCC([AsH3])=CC1=O</smiles><smiles>CC1(C)CCC(C[AsH])=CC1=O</smiles><smiles>CC1(C)CCC([18OH])CC1=O</smiles><smiles>CC1(C)CC(=O)C=C([AsH3])C1</smiles><smiles>CC1(C)CC(=O)C=C(C[AsH2])C1</smiles><smiles>CC1(C)CC(=O)C=C(CC[AsH3])C1</smiles>

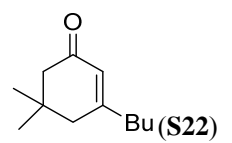<smiles>CCC1=CC(=O)CCC1(C)C</smiles>

Unless stated, reaction conditions are $\left(\mathrm{S}, \mathrm{S}^{\prime}\right)-7(3 \mathrm{~mol} \%), \mathrm{H}_{2} \mathrm{O}_{2}$ (2.3 equiv) and 2-eha (1.4 equiv.) in $\mathrm{CH}_{3} \mathrm{CN}$ at $-30^{\circ} \mathrm{C}$ during 30 min. ${ }^{a}$ Substrate conversion and epoxide yields (in parenthesis) determined by GC. ${ }^{b} 10 \mathrm{~mol} \%$ catalyst. Ee's determined by GC with a chiral stationary phase.

Remarkably, cyclohexene-1-ketones were also epoxidized in good yields and excellent enantioselectivities. Optimum stereoselectivities were obtained with different alkyl chains (87-92 \% ee, Table 3, entries 1-3). For branched groups, such as tert-butyl and cyclopropyl the enantioselectivities decreased slightly (entries 4 and 5), and a significant decrease in enantioselectivity was also obtained for the 5 membered cyclopentene rings (entry 6). Of interest is the observation that the epoxidation of the cyclopropyl derived substrate produces the epoxide without detectable amounts of cyclopropane ring opening products.

The relevance of the levels of enantioselectivity obtained with 7 can be best estimated when reactions are placed into context with the methodologies reported in the literature (Scheme 1). For comparison, a single example exists in the literature where the related allylic alcohol is epoxidized with excellent ee's by using Sharpless epoxidation, then followed by the oxidation of the alcohol to the ketone using $\mathrm{CoCl}_{2}$ (Scheme 1, a). ${ }^{52}$ On the other hand, direct epoxidation of the ketone has been performed with modest enantioselectivity using a chiral hydroperoxide (Scheme $1, b$ ). ${ }^{38}$ To the best of our knowledge, this is the first example of a catalytic methodology that can epoxidize this kind of olefins with excellent ee's.

Table 3. Substrate scope with 7 as catalyst
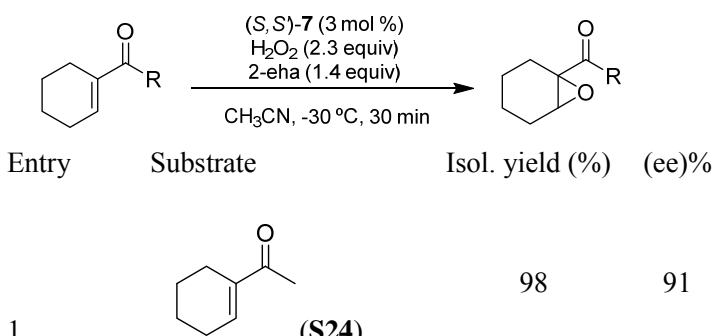

98

(S24)<smiles>CCC(=O)C1=CCCCC1</smiles><smiles>CCCC(=O)C1=CCCCC1</smiles>

80<smiles>CC(C)(C)C(=O)C1=CCCCC1</smiles>

88 


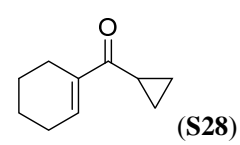

65<smiles>CC(=O)C1=CCCC1</smiles>

100(74)

(S29)
${ }^{\mathrm{b}} 6$

Unless stated, reaction conditions are (S,S')-7 (3 mol\%), $\mathrm{H}_{2} \mathrm{O}_{2}$ (2.3 equiv) and 2-eha (1.4 equiv.) in $\mathrm{CH}_{3} \mathrm{CN}$ at $-30^{\circ} \mathrm{C}$ during 30 min. ${ }^{a} 4$ mol \% catalyst. ${ }^{b}$ Epoxide yields and substrate conversion determined by GC for numbers in parenthesis. Ee's determined by GC with a chiral stationary phase.

Scheme 1. Examples in the literature for epoxidation of 1acetyl-1-cyclohexene

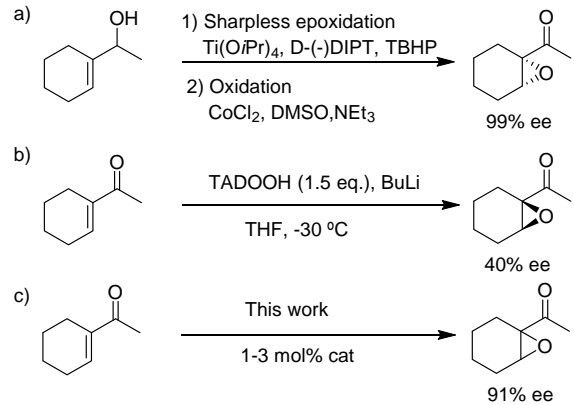

Mechanistic studies. Asymmetric epoxidation of cyclic enones has been so far performed via nucleophilic attack of peroxide agents at the olefinic site, activated via formation of an imine/iminium from reaction between the ketone moiety and a primary/secondary amine organocatalyst. This can be regarded as a variant of the Weitz-Scheffer epoxidation mechanism, where a basic peroxide is responsible for the initial attack at the $\beta$ carbon of the unsaturated carbonyl compound (Scheme 2a). ${ }^{46-51}$ On the other hand, activation of $\mathrm{H}_{2} \mathrm{O}_{2}$ by iron catalysts is most commonly leading to electrophilic oxidants, and this has proven the case for the enantioselective epoxidation of aromatic enones with 1. . $^{2,22,53-56}$ Nevertheless, examples for nucleophilic behavior have been also documented for related catalysts in olefin oxidation reactions. ${ }^{57}$ Mechanistic studies were therefore performed to address this question. Evidence for the presence of an electrophilic oxidant was gathered by competitive epoxidation of a mixture of cyclohexene (S30) and 2cyclohexenone $(\mathbf{S} \mathbf{1})$ under oxidant limiting conditions, observing that the epoxidation only takes place at the more electron-rich olefin (Scheme za). Likewise, the more electron-deficient enone $\boldsymbol{S}_{3} \mathbf{1}$ could not be epoxidized (Scheme 3b).

Further mechanistic studies indicate the reaction mechanism of these iron catalysts is highly reminiscent of the one operating in $\mathrm{P}_{45 \mathrm{O}^{58,59}}$ and in non-heme iron dependent oxygenases such as the family of Rieske oxygenases. ${ }^{60,61}$ In first place isotopic analysis shows that hydrogen peroxide is the exclusive source of oxygen atoms that end up in the epoxide (Scheme 3c), discarding water and atmospheric $\mathrm{O}_{2}$ as alternative sources. Indeed, reactions with $\mathrm{O}_{2}$ as the sole oxidant do not produce the epoxide. In addition, the use of tert-butyl hydroperoxide instead of hydrogen peroxide in the catalytic oxidation of 2-cyclohexenone yields the epoxide in $50 \%$ of yield and 91 $\%$ ee (compare with $75 \%$ yield and 90\% ee with $\mathrm{H}_{2} \mathrm{O}_{2}$ ). The virtually common stereoselectivity irrespective of the oxidant employed constitutes strong evidence that a common oxygen atom transfer agent is formed with both oxidants. Therefore, the sum of the experimental observations are consistent with a mechanistic scheme early proposed for structurally related catalysts ${ }^{23}$ where the carboxylic acid (2-eha) assists the cleavage of the $\mathrm{O}-\mathrm{O}$ bond, forming a carboxylate bound high valent $\mathrm{Fe}=\mathrm{O}$ species, which is highly electrophilic and performs the oxygen atom transfer reaction (Scheme $2 \mathrm{~b}$ ).

a) via nucleophilic oxidant<smiles>CC(O)C[C@H]1CCC(=O)O1</smiles>

b) via electrophilic oxidant

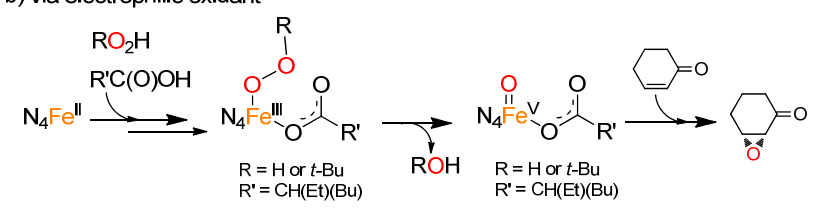

Scheme 2. Mechanistic scenarios for the asymmetric epoxidation of a cyclic enone. A) Nucleophilic Weitz-Scheffer epoxidation mechanism and B) Electro-
A)
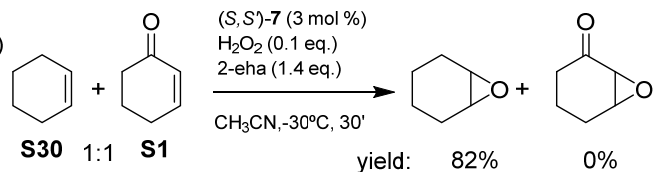

B)
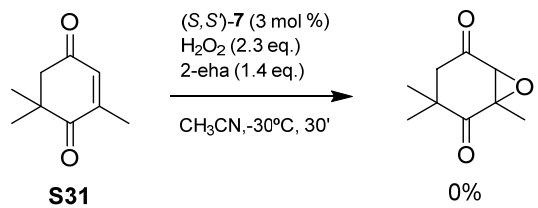

C)
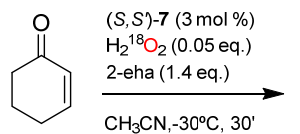

s1

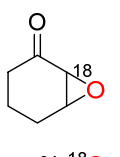

$98 \%{ }^{18} \mathrm{O}$ philic oxidation via a high valent iron oxo species. ${ }^{22}$

Scheme 3. (a) Competitive epoxidation experiment of cyclohexene (S30) and 2-cyclohexenone (S1), (b) the epoxidation of electron deficient olefin $\mathbf{S}_{3} \mathbf{1}$ and (c) epoxidation of $\mathrm{S1}$ using $\mathrm{H}_{2}{ }^{18} \mathrm{O}_{2}$

Regioselective epoxidation of diolefins. The electrophilic character of the active species can indeed find utility in the oxidation of substrates bearing olefinic moieties with 
distinct electronic properties. Thus, substrates $\mathbf{S}_{32}-\mathbf{S}_{39}$ were subjected to oxidation under standard conditions using ${ }^{\mathrm{Me} 2 \mathrm{~N}} \mathbf{1}$ or 7 , providing the product resulting from epoxidation at the more e-rich site in excellent yields and stereoselectivities Scheme 4, right, 94-99\% ee). Instead, epoxidation with basic hydrogen peroxide $\left(t-\mathrm{Bu}_{-} \mathrm{NH}_{2}\right.$ and $\mathrm{H}_{2} \mathrm{O}_{2}$ ) provided preferential oxidation at the cyclic aliphatic enone (59\% yield, along with $6 \%$ of a diepoxide, Scheme 4 left more details SI). Therefore, asymmetric epoxidation with these iron catalysts is orthogonal with enamine catalysis.

Scheme 4. Asymmetric epoxidation of dienones with ${ }^{\text {Me2N }} \mathbf{1}$ or 7 as catalysts (right) and with basic $\mathrm{H}_{2} \mathrm{O}_{2}$ (left)

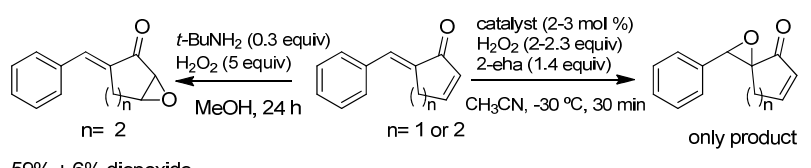

$59 \%+6 \%$ diepoxide

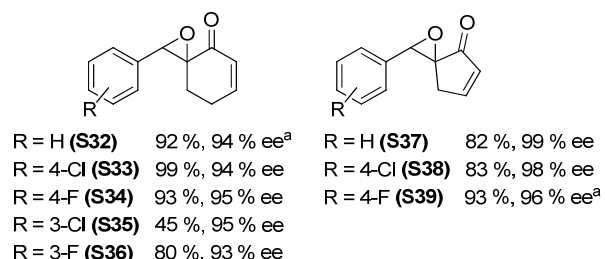

Unless stated, reaction conditions are $(S, S)-{ }^{\mathrm{Me} 2 \mathrm{~N}} \mathbf{1}(2 \mathrm{~mol} \%), \mathrm{H}_{2} \mathrm{O}_{2}$ ( 2 equiv) and 2-eha (1.4 equiv.) in $\mathrm{CH}_{3} \mathrm{CN}$ at $-30^{\circ} \mathrm{C}$ during 30 min. ${ }^{a}$ (S,S')-7 (3 mol\%), $\mathrm{H}_{2} \mathrm{O}_{2}$ (2.3 equiv) and 2-eha (1.4 equiv.) in $\mathrm{CH}_{3} \mathrm{CN}$ at $-30^{\circ} \mathrm{C}$ during $30 \mathrm{~min}$. ${ }^{\mathrm{b}}$ Ee's determined by HPLC with a chiral stationary phase.

Conclusion. In conclusion this work describes high yield and highly enantioselective epoxidation of cyclic enones with a $C_{1}$ symmetric iron coordination complex that combines a bulky pyridine and a benzylimidazole in its structure. Reactions are performed in short reaction times, employing aqueous hydrogen peroxide as oxidant. These features make this system a compelling alternative to methodologies with cinchona alkaloid organocatalysts, in some cases complementing its substrate scope. Furthermore, this work constitutes the first example where highly enantioselective (>90\% ee) epoxidation of non aromatic substrates with iron catalysis is described, and also the first example of an enantioselective electrophilic oxidation of this challenging class of substrates. This element confers the system with an orthogonal selectivity with regard to enamine catalysis that can find use in the site selective enantioselective epoxidation of polyene substrates. Finally, the design of $C_{1}$ symmetric complexes where the electronic and steric properties of distinct heterocycles are combined constitutes a novel aspect in the design of this class of catalysts. Further studies will be devoted to extend the development of this class of catalysts in order to improve enantioselectivities and to expand their application to oxidation of other families of challenging substrates.

Supporting Information. Experimental details for the preparation and characterization of ligands and metal complexes. Experimental details of catalytic reactions, and spectroscopic data for product characterization. "This material is available free of charge via the Internet at http://pubs.acs.org."

\section{Corresponding Author}

* Dr. M. Costas. QBIS-CAT Research Group, Institut de Química Computacional i Catàlisi (IQCC), Departament de Química, Universitat de Girona, Campus Montilivi, Girona E17071, Catalonia, Spain. Tel: +34-972419842, email: quel.costas@udg.edu.

* Prof. Robertus J.M. Klein Gebbink. ${ }^{2}$ Organic Chemistry \& Catalysis, Debye Institute for Nanomaterials Science, Utrecht University. Universiteitsweg 99, 3584 CG Utrecht, The Netherlands. Email: R.J.M.KleinGebbink@uu.nl

\section{ACKNOWLEDGMENT}

We acknowledge financial support from European Research Council (ERC-2009-StG-239910), MINECO of Spain (CTQ2012-37420-Co2-01/BQU, Consolider-Ingenio CSD2010ooo65) and the Catalan DIUE of the Generalitat de Catalunya (2009SGR637). X.R. and M.C. thank ICREA-Academia awards. We thank STR's from UdG for technical support.

\section{REFERENCES}

(1) Matsumoto, K.; Katsuki, T. In Catalytic Asymmetric Synthesis, Third Edition (ed I. Ojima); John Wiley \& Sons, Inc., Hoboken, NJ: 2010, p 839.

(2) De Faveri, G.; Ilyashenko, G.; Watkinson, M. Chem. Soc. Rev. 2011, 40, 1722.

(3) Zhu, Y.; Wang, Q.; Cornwall, R. G.; Shi, Y. Chem. Rev. 2014, 114, 8199.

(4) Davis, R. L.; Stiller, J.; Naicker, T.; Jiang, H.; Jørgensen, K. A. Angew. Chem. Int. Ed. 2014, 53, 7406.

(5) Que, L.; Tolman, W. B. Nature 20o8, 455, 8.

(6) Enthaler, S.; Junge, K.; Beller, M. Angew. Chem. Int. Ed. 2008, 47, 3317.

(7) Correa, A.; Mancheno, O. G.; Bolm, C. Chem. Soc. Rev. 2008, 37, 1108.

(8) Bauer, E. B. Curr. Org. Chem. 20o8, $12,1341$.

(9) Liang-Xian, L. Curr. Org. Chem. 2010, 14, 1099.

(10) Darwish, M.; Wills, M. Catal. Sci. Technol. 2012, 2, 243.

(11) Gopalaiah, K. Chem. Rev. 2013, 113, 3248.

(12) Cusso, O.; Ribas, X.; Costas, M. Chem. Commun. 2015, 51, 14285 .

(13) Gelalcha, F. G. Adv. Synth.E Cat. 2014, 356, 261.

(14) Wang, C.; Yamamoto, H. Chem. As. J. 2015, 10, 2056.

(15) Fingerhut, A.; Serdyuk, O. V.; Tsogoeva, S. B. Green Chem. 2015, 17, 2042.

(16) For selected examples of Fe-catalyzed epoxidation reactions see a) White, M. C.; Doyle, A. G.; Jacobsen, E. N. J. Am. Chem. Soc. 2oo1, 123, 7194. b) Chen, K.; Costas, M.; Kim, J.; Tipton, A. K.; Que Jr., L., J. Am. Chem. Soc. 2002, 124, 3026. c) Dubois, G.; Murphy, A.; Stack, T. D. P., Org. Lett. 2003, 5, 2469. d) Bukowski, M. R.; Comba, P.; Lienke, A.; Limberg, C.; de Laorden, C. L.; Mas-Balleste, R.; Merz, M.; Que, L. Jr. Angew. Chem. Int. Ed. 2006, 45, 3446. e) Anilkumar, G.; Bitterlich, B.; Gelalcha, F. G.; Tse, M. K.; Beller, M., Chem. Commun. 2007, 3, 289. f) Liu, P.; Wong, E. L.; Yuen, A. W.; Che, C., Org. Lett. 2oo8, 10, 3275. g) Company, A.; Feng, Y.; Güell, M.; Ribas, X.; Luis, J. M.; Que, L., Jr.; Costas, M. Chem. Eur. J. 2009, 15, 3359. h) Schröder, K.; Enthaler, S.; Join, B.; Junge, K.; Beller, M., Adv. Synth. Catal. 2o10, 352, 1771. i) Schroeder, K.; Enthaler, S.; Bitterlich, B.; Schulz, T.; 
Spannenberg, A.; Tse, M. K.; Junge, K.; Beller, M., Chem. Eur. J. 2009, 15, 5471. j) Schröder, K.; Join, B.; Amali, A. J.; Junge, K.; Ribas, X.; Costas, M.; Beller, M., Angew Chem. Int. Ed. 2011, 5o, 1425. k) Mikhalyova, E. A.; Makhlynets, O. V.; Palluccio, T. D.; Filatov, A. S.; Rybak-Akimova, E. V., Chem. Commun. 2012, 48, 687. l) Perandones, B. F.; Nieto, E. D.; Godard, C.; Castillon, S.; De Frutos, P.; Claver, C., ChemCatChem 2013, 5, 1092. m) Skobelev, I. Y.; Kudrik, E. V.; Zalomaeva, O. V.; Albrieux, F.; Afanasiev, P.; Kholdeeva, O. A.; Sorokin, A. B., Chem. Commun. 2013, 49, 5577. n) Clemente-Tejeda, D.; López-Moreno, A.; Bermejo, F. A., Tetrahedron 2013, 69, 2977. o) Kuck, J. W.; Raba, A.; Markovits, I. I. E.; Cokoja, M.; Kuhn, F. E., ChemCatChem 2014, 6, 1882. p) Chishiro, T.; Kon, Y.; Nakashima, T.; Goto, M.; Sato, K. Adv. Synth. E Cat. 2014, 356, 623. q) Kück, J. W.; Anneser, M. R.; Hofmann, B.; Pöthig, A.; Cokoja, M.; Kühn, F. E. Chemsuschem 2015, 8, 4056 .

(17) Oloo, W. N.; Que, L. Jr. Acc. Chem. Res. 2015, 48, 2612.

(18) Talsi, E. P.; Bryliakov, K. P. Coord. Chem. Rev. 2012, 256, 1418.

(19) Gelalcha, F. G.; Bitterlich, B.; Anilkumar, G.; Tse, M. K.; Beller, M. Angew Chem. Int. Ed. 2007, 46, 7293.

(20) Wang, B.; Wang, S.; Xia, C.; Sun, W. Chem. Eur. J. 2012, 18, 7332.

(21) Lyakin, O. Y.; Ottenbacher, R. V.; Bryliakov, K. P.; Talsi, E. P. Acs Catal. 2012, 2, 1196.

(22) Cussó, O.; Garcia-Bosch, I.; Ribas, X.; Lloret-Fillol, J.; Costas, M. J. Am. Chem. Soc. 2013, 135, 14871.

(23) Cussó, O.; Ribas, X.; Lloret-Fillol, J.; Costas, M. Angew. Chem. Int. Ed. 2015, 54, 2729.

(24) Nishikawa, Y.; Yamamoto, H. J. Am. Chem. Soc. 2011, 133, 8432.

(25) Niwa, T.; Nakada, M. J. Am. Chem. Soc. 2012, 134, 13538.

(26) Luo, L.; Yamamoto, H. Eur. J. Org. Chem. 2014, $2014,7803$.

(27) Dai, W.; Li, G.; Chen, B.; Wang, L.; Gao, S. Org. Lett. 2015 , 17,904 .

(28) Kaku, Y.; Otsuka, M.; Ohno, M. Chem. Lett. 1989, 18, 611.

(29) Francis, M. B.; Jacobsen, E. N. Angew. Chem. Int. Ed. 1999, $38,937$.

(30) Cheng, Q. F.; Xu, X. Y.; Ma, W. X.; Yang, S. J.; You, T. P. Chin. Chem. Lett. 2005, 16, 1467.

(31) a) Marchi-Delapierre, C.; Jorge-Robin, A.; Thibon, A.; Ménage, S. Chem. Commun. 20o7, 11, 1166. b) Oddon, F.; Girgenti, E.; Lebrun, C.; Marchi-Delapierre, C.; Pecaut, J.; Menage, S. Eur. J. Inorg. Chem. 2012, 85 .

(32) a) Gelalcha, F. G.; Anilkumar, G.; Tse, M. K.; Brückner, A.; Beller, M. Chem. Eur. J. 2oo8, 14, 7687.

(33) Yeung, H.-L.; Sham, K.-C.; Tsang, C.-S.; Lau, T.-C.; Kwong, H.-L. Chem. Commun. 2008, 3801.

(34) Wu, M.; Miao, C.-X.; Wang, S.; Hu, X.; Xia, C.; Kühn, F. E.; Sun, W. Adv. Synth. E Catal. 2011, 353, 3014.

(35) Wang, B.; Lee, Y.-M.; Seo, M. S.; Nam, W. Angew. Chem. Int. Ed. 2015, 54, 11740.

(36) Lee, A.; Reisinger, C. M.; List, B. Adv. Synt. Catal. 2012, 354, 1701.

(37) Uteuliyev, M. M.; Nguyen, T. T.; Coltart, D. M. Nat Chem 2015, 7, 1024.

(38) Aoki, M.; Seebach, D. Helv. Chim. Acta 20o1, 84, 187.

(39) Kienle, M.; Argyrakis, W.; Baro, A.; Laschat, S. Tetrahedron Lett. 2008, 49, 1971.

(40) Julia, S.; Guixer, J.; Masana, J.; Rocas, J.; Colonna, S.; Annuziata, R.; Molinari, H. J. Chem. Soc., Perkin Trans. 1 1982, 1317.

(41) Macdonald, G.; Alcaraz, L.; Lewis, N. J.; Taylor, R. J. K. Tetrahedron Lett. 1998, 39, 5433.

(42) Barrett, A. G. M.; Blaney, F.; Campbell, A. D.; Hamprecht, D.; Meyer, T.; White, A. J. P.; Witty, D.; Williams, D. J. J. Org. Chem. 2002, 67, 2735.
(43) Adam, W.; Rao, P. B.; Degen, H.-G.; Levai, A.; Patonay, T.; Saha-Möller, C. R. J. Org. Chem. 2002, 67, 259.

(44) Wang, B.; Miao, C.-X.; Wang, S.-F.; Kühn, F. E.; Xia, C.-G.; Sun, W. J. Organomet. Chem. 2012, 715, 9.

(45) Wang, B.; Miao, C.; Wang, S.; Xia, C.; Sun, W. Chem. Eur. J. 2012, 18,6750 .

(46) Weitz, M. S., A. Chem. Ber. 1921, 54, 2327.

(47) Wang, Z. In Comprehensive Organic Name Reactions and Reagents; John Wiley \& Sons, Inc.: Hoboken, NJ, 2010.

(48) Bunton, C. A.; Minkoff, G. J. J. Chem. Soc. (Resumed) 1949, 665 .

(49) House, H. O.; Ro, R. S. J. Am. Chem. Soc. 1958, 8o, 2428.

(50) Kelly, D. R.; Caroff, E.; Flood, R. W.; Heal, W.; Roberts, S. M. Chem. Commun. 2004, 2016.

(51) Kelly, D. R.; Roberts, S. M. Pept. Sci. 20o6, 84, 74.

(52) Nomura, K.; Matsubara, S. Chem. As. J. 2010, 5, 147.

(53) Mas-Balleste, R.; Que, L., Jr. J. Am. Chem. Soc. 2007, 129, 15964 .

(54) Lyakin, O. Y.; Zima, A. M.; Samsonenko, D. G.; Bryliakov, K. P.; Talsi, E. P. Acs Catal. 2015, 5, 2702.

(55) Wang, Y.; Janardanan, D.; Usharani, D.; Han, K.; Que, L.; Shaik, S. Acs Catal. 2013, 3, 1334.

(56) Lyakin, O. Y.; Bryliakov, K. P.; Talsi, E. P. Inorg. Chem. 2011, $50,5526$.

(57) Fujita, M.; Costas, M.; Que, J., L. J. Am. Chem. Soc. 2003, 125, 9912.

(58) Shaik, S.; Cohen, S.; Wang, Y.; Chen, H.; Kumar, D.; Thiel, W. Chem. Rev. 2010, 110, 949.

(59) Meunier, B.; de Visser, S. P.; Shaik, S. Chem. Rev. 2oo4, 104, 3947.

(6o) Chakrabarty, S.; Austin, R. N.; Deng, D.; Groves, J. T.; Lipscomb, J. D. J. Am. Chem. Soc. 2007, 129, 3514.

(61) Barry, S. M.; Challis, G. L. Acs Catal. $2013,3,2362$.

(62) Lifchits, O.; Mahlau, M.; Reisinger, C. M.; Lee, A.; Fares, C.; Polyak, I.; Gopakumar, G.; Thiel, W.; List, B. J. Am. Chem. Soc. 2013, 135, 6677 . 


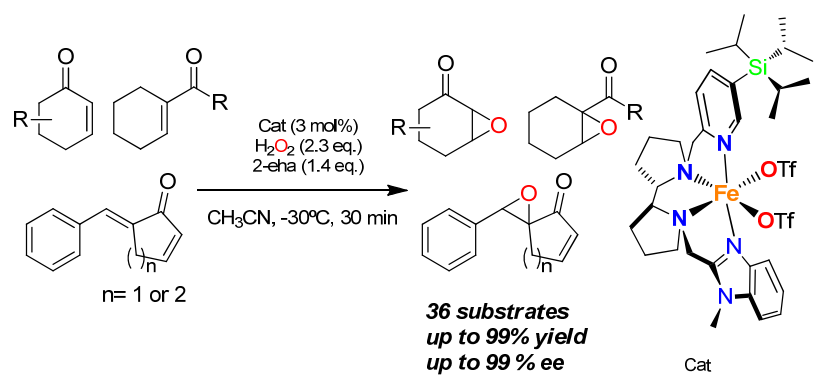

